\title{
The Bricker Amendment and Congress's Failure to Check the Inflation of the Executive's Foreign Affairs Powers, 1951-1954
}

\author{
By Nelson Richards $\dagger$
}

\section{INTRODUCTION}

Not everyone who perceives a problem in the Constitution takes it upon himself to fix it. Yet, in the 1940s, an attorney from Seattle named Frank Holman did just that. He noticed what he considered to be a major threat to the American way of life: a loophole in the Constitution that allowed treaties to abrogate the Bill of Rights. To Holman, the judicial and executive branches' handling of international affairs was placing America in dire straits. He feared that "the domestic laws and the domestic rights of the American people, and even our form of government, could be changed and even destroyed by international pacts, covenants, [and] treaties." Treaties and executive agreements, he felt, were gradually opening the country up to undesirable foreign influence and manipulation.

As a successful lawyer and president of the American Bar Association, Holman was uniquely situated to prevent his fears from coming true. ${ }^{2} \mathrm{He}$ began a quest that would last almost a decade and spawn multiple proposed amendments to the Constitution limiting the executive's ability to enter into, and the judiciary's ability to enforce, international agreements. The numerous articles he wrote for the American Bar

\footnotetext{
Copyright $(2006$ Califomia Law Review, Inc. California Law Review, lnc. (CLR) is a California nonprofit corporation. CLR and the authors are solely responsible for the content of their publications.

$\dagger \quad$ J.D. Candidate, School of Law, University of Califomia, Berkeley (Boalt Hall), 2006; B.A., University of California, Santa Barbara, 2003. The author would like to thank his editor, Tina Wong, and the CLR editing teams for all their hard work. He would also like to thank Professor Hal Drake, Professor Mary Furner, and Lee Shaker-great historians all-for their invaluable instruction in the art and craft of writing history, and Professor Harry Scheiber for suggesting a gold mine of a topic.

1. Frank E. Holman, Story of the "Bricker Amendment” 8 (1954).

2. In addition to his position at the head of the ABA, Holman was a former Rhodes Scholar who had earned his law degree from Oxford and had served as dean of the University of Utah's law school for two years. See Treaties and Executive Agreements: Hearings Before a Subcomm. of the Judiciary of the United States Senate, 83d Cong. 130-131 (1953) [hereinafter 1953 Hearingsl (statement of Frank Holman).
} 
Association Journal ${ }^{3}$ had a profound effect on Senator John Bricker of Ohio, who would become the political champion and namesake of Holman's movement to amend the Constitution. Through him the so-called Bricker Amendment was born, and through his efforts the matter came before the Senate.

Senator Bricker picked up Holman's standard of his own accord and bore it throughout the rise and fall of the ensuing controversy, eventually letting it consume his political career. ${ }^{4}$ With training in law and an impressive political resume-including serving as Attorney General of Ohio (1933-37), Governor of Ohio (1939-45), a two-term U.S. Senator (1946 and 1952), and an unsuccessful Republican candidate for Vice President (1944) - Bricker was perfect for the job. ${ }^{5} \mathrm{He}$ was a dedicated Republican with a grandfatherly mien, but he could be a shrewd political adversary; he knew how to pull his opposition's political strings and did not hesitate to do so. ${ }^{6}$

Together, Bricker and Holman recruited an army of lawyers, judges, politicians, businessmen, social organizations, and private citizens to support their amendment. They used a mixture of anti-communist, antisocialist, and anti-internationalist sentiment as their rallying cry. The United Nations sat squarely in their sights. Though Bricker and Holman viewed communism as the bigger threat, they painted the U.N. as an insidious and pervasive organization that would tear away American freedoms and replace them with Socialist and totalitarian policies. Part and parcel of this ideology was the argument that the President had gained too much power, which, in a time of increasing executive cooperation with new international bodies, made the nation more susceptible to U.N. influence. The Bricker Amendment responded to the growth in executive power and the sources of that growth.

The twentieth century witnessed the rise of the executive, especially after World War II and especially in foreign affairs. ${ }^{7}$ A confluence of factors led to the centralization of foreign affairs powers in the President, but none was as important as the Cold War. Many in power viewed the

3. See, e.g., Frank E. Holman, An "International Bill of Rights": Proposals Have Dangerous Implications for U.S., 34 A.B.A. J. 984 (1948); Frank Holman, Must America Succumb to Statism?, 35 A.B.A. J. 801 (1949); Frank E. Holman, Treaty Law-Making: A Blank Check for Writing a New Constitution, 36 A.B.A. J. 707 (1950).

4. Holman, supra note 1 , at 12.

5. Biographical Directory of the United States Congress, at http://bioguide.congress.gov/scripts/ biodisplay.pl?index $=\mathrm{B} 000820$ (last visited Jan. 1, 2005).

6. For example, in 1949 Bricker tried to split Democrats along north-south lines on a housing bill, which purportedly would have cleaned up public housing slums, by sponsoring an amendment to the bill calling for desegregation in new public housing. Though he did not succeed, the plan hinted at his willingness to employ chameleonic political techniques. See Clayton Knowles, Big Housing Bill Passed By Senate: Bar on Bias Fails, N.Y. Times, Apr. 22, 1949, at 1.

7. Gordon Silverstein, Imbal ance of Powers: Constitutional Interpretation and the Making of American Foreign Policy 68 (1997). 
bourgeoning conflict with the U.S.S.R. as a "menace" and an "unexpected crisis [that] hung over the world, demanding ... the concentration within government of the means of instant decision and response." Congress, a deliberative body, was not equipped to make the split-second decisions that the nuclear threat warranted. Nor could it make decisions quickly enough to nip potential diplomatic problems in the bud. Presidents, generally keen on expanding their power, leapt at the chance offered by the Cold War. For instance, Harry Truman, seizing the opportunity to expand his authority, started the Cold War power grab with a bang, sending troops into Korea in an unprecedented circumvention of Congress's power to declare war. ${ }^{9} \mathrm{He}$ justified his actions in part by pointing to U.S. commitments to the U.N. ${ }^{10}$ Shortly thereafter, Truman sent troops into Europe to meet NATO obligations, again without consulting Congress. ${ }^{11}$

Truman's moves to expand executive power were not all successful, however. Most notably, he failed in efforts to seize the steel industry in order to prevent a strike, which could have crippled the war effort in Korea. ${ }^{12}$ But it was the Supreme Court that checked his actions, not Congress. What's more, the decision was by a Court at loggerheads, unable to definitively expound the constitutional role of the executive in foreign affairs. Congress's balance with the executive seemed to be entering obsolescence and the judiciary appeared equally unable to provide that balance.

The President's gains were not the only reallocations of power during the twentieth century. Despite power within the federal government shifting strongly toward the executive branch, the other branches enjoyed newfound sources of power as well, often at the expense of state autonomy. Congress had its domestic powers drastically expanded by the Court's liberal interpretation of the Commerce Clause. ${ }^{13}$ The federal courts enjoyed increasing influence as arbiters of the limits of executive and congressional authority, and, with the rise of the civil rights movement, as the branch most willing to effect social change.

Thus, the Cold War brought a flow of power upward to the federal government and inward to the executive branch. Bricker and Holman tried to stop this trend. They wanted to reassert congressional power in the federal government and at the same time stem the federal government's

8. Arthur Schlesinger Jr., The Imperial Presidency 128 (1973).

9. SILVERSTEIN, supra note 7, at 69 .

10. Id.

11. Id. at 71 .

12. See Youngstown Sheet \& Tube Co. v. Sawyer, 343 U.S. 579 (1952).

13. See, e.g., Wickard v. Filburn, 317 U.S. 111 (1942) (aggregating personal, local, and individual economic activity to determine whether such activity could be regulated by Congress pursuant to the Commerce Clause). 
erosion of state power. To their minds, the horizontal and vertical separation of powers had strayed too far from the Framers' original intent. ${ }^{14}$

The amendment sought to effect change by securing states' rights and giving Congress a tool to rein in the President. Although there were many different incarnations of the amendment, the basic concepts remained roughly the same. The final text that the Committee on the Judiciary submitted to the Senate in June 1953 read:

Section 1. A provision of a treaty which conflicts with this Constitution shall not be of any force or effect.

Section 2. A treaty shall become effective as internal law in the United States only through legislation which would be valid in the absence of treaty.

Section 3. Congress shall have power to regulate all executive and other agreements with any foreign power or international organization. All such agreements shall be subject to the limitations imposed on treaties by this article. ${ }^{15}$

Despite the fact that the amendment was not enacted, some scholars argue that the debate resulted in the United States' longstanding aversion to human rights treaties and the supra-national organizations that monitor and enforce them. ${ }^{16}$ For Louis Henkin, the history is simple: "Senator Bricker lost his battle, but his ghost is now enjoying victory in war. For the package of reservations, understandings and declarations" that plague modernday treaty negotiations, "achieves virtually what the Bricker Amendment sought, and more."17 Determining the veracity of such a claim is difficult, and Henkin's motives are dubious. His animadversions on the influence of the Bricker Amendment act as a foil to prop up an argument for increased U.S. involvement in multilateral treaty regimes. In the same breath, in which he declaims Senator Bricker's injurious legacy, Henkin calls for "[a]ll who are committed to international human rights" to encourage the United States to only make reservations that are "constitutionally required," to "reexamine the reservations it has" on current human rights treaties for constitutional necessity, to "abandon its practice of declaring human rights conventions non-self-executing," and to participate in

14. Gordon Silverstein aptly explains the difference between the horizontal and vertical separation of powers. The horizontal separation of powers is that allotted by the Constitution to the three branches of the federal government. The vertical separation of powers is that between the states and the federal government. See SILVERSTEIN, supra note 7, at 22.

15. S. REP. No. 412 , at 1 (1953) [hereinafter Judiciary Report]. Sections 4 and 5 of the Amendment gave Congress the power to enforce the Amendment and outlined the ratification process.

16. See Louis Henkin, U.S. Ratification of Human Rights Conventions: The Ghost of Senator Bricker, 89 AM. J. INT'L. L. 341 (1995); Natalie Hevener Kaufman \& David Whiteman, Opposition to Human Rights Treaties in the United States Senate: The Legacy of the Bricker Amendment, 10 HuM. RTs. Q. 309 (1988); Stephen A. Garret, Foreign Policy and the American Constitution: The Bricker Amendment in Contemporary Perspective, 16 INT'L. STUD. Q. 187 (1972).

17. Henkin, supra note 16 , at 349 . 
"disputes under the human rights conventions" in the International Court of Justice. ${ }^{18}$ Such an approach misses the lesson of the Bricker Amendment.

Vestiges of the controversy surrounding the Bricker Amendment persist because the fundamental problems identified by Holman and Bricker were never resolved, not because they tainted Congress's attitude towards treaties. States' rights and anti-communist rhetoric belied valid questions as to the proper method for integrating the United States into a then emerging - and today, still emergent-international framework. It is not axiomatic that the executive branch should have such a heavy hand in foreign policy. The Constitution gives Congress numerous responsibilities in foreign affairs: the power to declare war, maintain the army and navy, regulate foreign commerce, and to advise and consent to all treaties and ambassadorial appointments. ${ }^{19}$ The twentieth century has witnessed an accrual of power to the executive in foreign affairs, backed by the judiciary, which should definitely be questioned, if not limited. A shrugging of shoulders, chalking up the tumid executive power to the advent of A-bombs and unanticipated emergencies, has led to surprising audacity on the part of recent presidents in an ever-increasing push to expand the executive fiefdom. ${ }^{20}$

Nor is it self-evident that the Constitution is compatible with the international framework laid out by the U.N. Charter. A frictionless path to an international lcgal order would have doomed the Charter from its birth. Those who wholeheartedly embraced the system failed to understand that the Charter they created was flawed in its optimism. There were no incentives to adopt it, nor any means of coercing the world to follow its strictures-not to mention any attempt to make the Charter compatible with the culturally divergent nations that were its target. It would be a misnomer to call Bricker and Holman internationalists in any sense of the word, but that does not mean that their qualms with the U.N. are any less valid, or that they were not necessary obstacles in the reification of the globalization of law. Issues they grappled with in the course of developing their amendment are still relevant today: individuals as subjects of international law and questions of enforcement were the two inost prominent problems.

That said, Constitutional amendments such as those introduced by Senator Bricker and other members of Congress were not the best way for Congress to regain its lost powers or to address the metamorphosis of international law after World War II. This Comment examines the history of the controversy, using it as a case study to explore the inability of Congress

\footnotetext{
18. Id. at 349-50.

19. U.S. Const. art. I, $\S 8$; see also Louis Fisher, The Politics of Shared Power: Congress AND THE EXECUTIVE 177-78 (1998).

20. See Section V.A and notes 212-I8, infra, for a brief treatment of the current Administration's attempts to expansively define executive power.
} 
to limit the executive. Part I looks at the Constitutional underpinnings of the treaty power and Missouri v. Holland, ${ }^{21}$ the case that Holman and Bricker thought opened the Constitution to undue foreign influence. Part II examines Senator Bricker's various proposals and the congressional debates leading up to the hearings before the Senate Judiciary Committee. Part III considers those hearings and the Committee's majority report, which recommended the amendment to the Senate, and the dissenting minority report. Part IV looks at the debates leading up to a vote and the vote itself. Finally, Part V explores the lessons the Bricker Amendment provides for reining in the executive's power in the realm of foreign affairs today.

\section{I}

Treaties, the Constitution, ANd Bricker's Bogeyman: Missouriv. HOLLAND

Holman and Bricker believed that a massive gap in the Constitution needed filling before a small group of internationalists, both within the United States and abroad, pilfered America's valued freedoms. ${ }^{22}$ The Supreme Court's 1920 decision, Missouri v. Holland, provided the avenue for the assault. "In the treaty-making power, as interpreted by Missouri v. Holland," Bricker wrote, "a way has been found to amend the Constitution by resorting to Article VI in preference to the more difficult method laid down in Article V. ${ }^{.23}$ Article VI, the Supremacy Clause, states:

This Constitution, and the Laws of the United States which shall be made in Pursuance thereof; and all Treaties made, or which shall be made, under the Authority of the United States, shall be the supreme Law of the Land; and the Judges in every State shall be bound thereby, any Thing in the Constitution or Laws of any State to the contrary notwithstanding. ${ }^{24}$

On its face, the Supremacy Clause suggests that treaties do not need to be made pursuant to the Constitution and therefore are not bound by its strictures, or so Holman and Bricker feared. Alexander Hamilton viewed the Supremacy Clause as "one of the best digested and most unexceptional parts of the [constitutional] plan." 25 And he was right; the impotency of American negotiators in peace talks with Britain under the Articles of

21. 252 U.S. $416(1920)$.

22. Frank E. Holman, The Increasing Need for a Constitutional amendment on Treaties and Executive Agreements 27 (1955) ("The 'Bricker' Amendment movement is a thorn in the side of all the one-worlders, half one-worlders, Atlantic Unionists, and other groups who seek to merge American Constitutional Government and 'our lives, our fortunes and our sacred honor' as safeguarded thereby-into some form of world order dominated by aliens and alien concepts of government.").

23. John W. Bricker, Making Treaties and Other International Agreements, 289 ANNALs AM. ACAD. Pol. \& Soc. SCI. 134, 136 (1953) (internal citations omitted).

24. U.S. ConST. art. Vl, cl. 2. (emphasis added).

25. The Federalist No. 75 (Alexander Hamilton). 
Confederation had taught the Framers that the power to make international agreements should be vested in the federal government. ${ }^{26}$ The negotiators, Benjamin Franklin and John Jay, conceded to British demands that pre-war debtors be held liable for their debts. However, many states, most notably New York and Virginia, refused to comply on the grounds that the several states had the power to determinc the validity of a treaty. The Framers took the lesson to heart, and they wasted little energy debating the merits of granting the federal government the power to make treaties. ${ }^{27}$ They also prohibited states from entering into treaties so that the nation spoke with one voice in foreign affairs. ${ }^{28}$

That voice would emanate from the executive, but would be checked by Congress. Article 1I, section 2 of the Constitution provided that, in addition to the role of "Commander in Chief of the Army and Navy of the United States," the President "shall have Power, by and with the Advice and Consent of the Senate, to make Treaties, provided two thirds of the Senators present concur."29 To add a second, if vague, check on the President's power, disputes in "Law and Equity" arising from treaties would fall under the power of the judiciary. ${ }^{30}$

Early Presidents used treaties sparingly. George Washington only entered into five during his eight years in office; John Adams entered into four; Thomas Jefferson, James Madison, and James Monroe entered into a total of eighteen in the twenty four years that comprised their presidencies. ${ }^{31}$ By 1920, when the Court decided Holland, Woodrow Wilson had entered into twenty-seven treaties in that term alone, and sixty-eight during his entire presidency. ${ }^{32}$ President Truman's second term (1949-52) resulted in seventy treaties; Eisenhower's first term (1953-56) resulted in ninety. ${ }^{33}$ Such a trend accorded with the United States' ascendancy as a global superpower and with the increased activity brought on by technological and commercial change. It was with those numbers in mind that Bricker reflected on Holland, the child of a very different epoch.

In Holland, the Court decided the narrow issue of whether the Migratory Bird Treaty Act of July 3, 1918, violated the Tenth Amendment. ${ }^{34}$ Behind the issue lay a long, drawn-out national and international debate

26. See David M. Golove, Treaty-Making and the Nation: The Historical Foundations of the Nationalist Conception of the Treaty Power, 98 Mich. L. Rev. 1075, $1119-20$ (2000).

27. Id. at 1127 .

28. See U.S. CoNST. art. I, $\S 10$ ("No State shall enter into any Treaty, Alliance, or Confederation.").

29. U.S. ConsT. art. $11, \S 2$.

30. See U.S. CONST. art. 111, §2.

31. Gary King \& Lyn Ragsdale, The Elusive Executive: Discovering Statistical Patterns in the Presidency 131-32 (1988).

32. Id. at 137.

33. Id. at 139

34. 252 U.S. 416,430 (1920). 
regarding the use and preservation of natural resources. Over the course of the nineteenth century, the unfettered competitive market economies of the United States and Canada, coupled with a general ignorance of biology and ecosystems, led to massive depletion of Great Lakes fisheries, Alaskan sea otters, and North American migratory bird populations. ${ }^{35}$ In response, conservationists lobbied Congress to pass federal legislation limiting the hunting of migratory birds. ${ }^{36}$

Three decisions, two from state supreme courts and one from a federal district court, ruled the law unconstitutional. ${ }^{37}$ Judge Trieber of the Eastern District of Arkansas held that the "Constitution is an enabling instrument, and therefore Congress possesses only such powers as are expressly or by necessary implication granted by that instrument...."38 Regulating wild game was not enumerated and therefore not within Congress's power. If citizens were unhappy, he reasoned, they could amend the Constitution. ${ }^{39}$ Thus, when President Taft and the Senate ratified the Migratory Bird Treaty, passing it into law with the Migratory Bird Treaty Implementing Act (MBTIA), ${ }^{40}$ some precedent indicated that analogous legislation was outside the federal government's enumerated powers.

As an issue of pure constitutional law, the conservationists' strategy made sense. Protecting migratory birds was not within the federal government's powers, but making treaties was. The path appeared logical under a legal rubric, but dubious under a political one. Three federal district courts saw the legal logic and held the MBTIA constitutional. ${ }^{41}$ In United States $v$. Thompson, Judge Trieber had a second stab at the problem, and finding his initial fears allayed, he held "To make treaties is one of the highest attributes of every sovereign government, and if the United States does not possess it to the fullest extent it would not be invested with the powers which belong to independent nations." 42 Again, he offered a consolation to the losing side: "while a treaty will supersede a prior act of Congress, an act of Congress may supersede a prior treaty." ${ }^{43}$ Meanwhile, the Supreme Court

35. See KurkPatrick Dorsey, The Dawn of Conservation Diplomacy (1998).

36. Appropriation Act for the Department of Agriculture of March 4, 1913, ch. 145, Pub. L. No. 430, 37 Stat. 828,847 ("[M]igratory game and other insectivorous birds which in their northern and southern migrations pass through or do not remain permanently the entire year within the borders of any State or Territory, shall hereafter be deemed to be within the custody and protection of the Government of the United States, and shall not be destroyed or taken contrary to regulations hereinafter provided therefor.').

37. United States v. Shauver, 214 F. 154 (E.D. Ark. 1914); State v. Sawyer, 94 A. 886 (Me. 1915); State v. McCullagh, 153 P. 557 (Kan. 1915).

38. Shauver, $214 \mathrm{~F}$. at 160 .

39. Id. at 156.

40. Migratory Bird Treaty Act of July 3, 1918, ch. 128, 65 Pub. L. No. 186, 40 Stat. 755.

41. See United States v. Thompson, 258 F. 257 (E.D. Ark. 1919); Samples v. De Lapp, 258 F. 479 (W.D. Mo. 1919); United States v. Selkirk, 258 F. 775 (S.D. Tex. 1919).

42. $258 \mathrm{~F}$. at 268 .

43. Id. 
granted certiorari in another MBTIA case from a different jurisdiction that pitted a U.S. game warden against the State of Missouri. ${ }^{44}$

Justice Holmes, writing for a unanimous Court, tried to answer the "general" question of "whether the treaty and statute are void as an

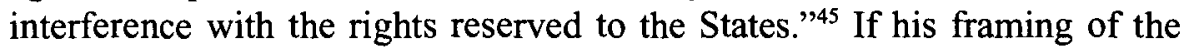
question was simple, his abstruse answer opened a Pandora's box. Charles A. Lofgren astutely identifies why the case caused so much confusion:

Holmes raised the question whether there were any limits to treaties so as to hint that there were none, and he then buried his actual answer-that is, his proposed limitations-in passages which lacked precision and were far more striking for their general constitutional ideas and aphorisms. As a result, he practically encouraged misinterpretation of the Court's decision. ${ }^{46}$

Indeed, Holmes stated, "We do not mean to imply that there are no qualifications to the treaty-making power; but they must be ascertained in a different way" than by acts of Congress. ${ }^{47}$ However, he failed to give any general rule as to how limits to the treaty power might be ascertamed. HoImes determined that the implementing legislation of the Migratory Bird Treaty was valid because "a national interest of very nearly the first magnitude [was] involved," and only action with Canada could curtail the abuse. ${ }^{48}$ But other than those specific considerations, no discernable rule could be found in the decision.

What does come across strongly in the opinion is an argument for an evolving Constitution, one that handles issues that "could not have been foreseen completely by the most gifted of its begetters. " ${ }^{39}$ Holmes labeled the Constitution an "organism," but lest he seem too whimsical, he followed with a sobering reminder of how the Framers' dream "has taken a century and has cost their successors much sweat and blood to prove that they created a nation." ${ }^{50}$ The allusion to the Civil War probably served to quell any states' rights grumbling about his cryptic reference to "invisible radiation from ... the Tenth Amendment" being unable to nullify the treaty. ${ }^{51}$ When it came down to it, in I920, there was very little fear that a treaty could alter the Constitution. Treaties of the sort that could do so had not yet emerged.

\footnotetext{
44. Missouri v. Holland, 252 U.S. 416 (1920).

45. Id. at 432 .

46. Charles A. Lofgren, Missouri v. Holland in Historical Perspective, 1975 Sup. CT. Rev. 77,

47. Holland, 252 U.S. at 433.

48. Id. at 435 .

49. Id at 433 .

50. Id.

51. Id at 434 .
} 113. 
By the 1950s, the scenario had changed. Bricker and Holman saw Holland as an open sluice through which the U.N. Charter could, among other things, abrogate state autonomy. ${ }^{52}$ Hence, Holland became the bugbear of the Bricker controversy, the source of fear that underscored all other anxieties.

II

LAYING THE GroundWORK: EARLy INCARNATIONS OF THE BRICKER AMENDMENT

Senator Bricker's tortuous quest to amend the Constitution comprised many attempts, revisions, and spin-offs proffered by other Senators. Starting in earnest in 1951, Bricker put pressure on Congress to adopt a resolution creating an amendment. He primed the pump with attacks on the U.N. and then tried his hand at a Senate resolution-Senate Joint Resolution 130 (S.J. Res. 130)-to stave off the evils of the outside world. ${ }^{53}$ The resolution fizzled in hearings before a subcommittee of the Committee on the Judiciary. ${ }^{54}$ Undiscouraged, Bricker came to the 83rd Congress in 1953 with Senate Joint Resolution 1 (S.J. Res. 1).$^{55}$ He thus began what would be a yearlong battle over the proper role of the executive's actions in the formation of treaties and international agreements.

Senator Bricker's first major stand against the U.N. vilified the U.N.'s Covenant on Human Rights in the early 1950s. Arguments he made about the dangers of the U.N. prefigured many of his arguments as to why Congress should contain the executive. Bricker mounted a dual offensive. On one front, he directly attacked the Covenant, which he argued would "repeal a substantial part of the Constitution." 56 On the other be attacked President Truman, whose recent speeches were, Bricker thought, "sufficient proof that he does not understand the legal principles on which this Republic was founded." He was, however, willing to grant Truman a concession: "It would be unfair to accuse him of planning to destroy a document of which he possesses so little understanding." ${ }^{57}$ Bricker labeled the Covenant a "blueprint for slavery" and a "monstrous document." 58 In his initial tirade, he focused on the Covenant's threat to America's

52. See Holman, supra note 1, at 27 ("Articles 55 and 56 of the United Nations Charter, with their broad provisions covering the whole field of human rights and activities-under the doctrine of Missouri vs. Holland can give to the Federal Government unlimited and unrestrained power over all local affairs, making it in faet a Federal Government of unlimited powers.").

53. S.J. Res. 130, 82d Cong. (1952).

54. Treaties and Executive Agreements: Hearings Before a Subcomm. of the Judiciary of the United States Senate, 82d Cong. (1953) [hereinafter 1952 Hearings].

55. S.J. Res. 1, 83d Cong. (1953).

56. 82 CONG. REC. 8263 (1951).

57. Id. (emphasis added).

58. 82 CoNG. ReC. 8255 (1951). 
cherished free press, beginning his trend of dire prognostications that the U.N. and its Charter would destroy the Constitution.

He encouraged the President to inform the U.N. that the Covenant was unacceptable to the United States and to withdraw U.S. representatives from associated negotiations. Bricker warned that, in addition to the press, public trials by jury and religious freedom would also fall victim to U.N. idealism. ${ }^{59}$ Recent history provided Bricker with a wealth of cautionary tales: Jawaharlal Nehru in India, Juan Perón in Argentina, ${ }^{60}$ Josip Broz Tito in Czechoslovakia, and Joseph Stalin in Russia.$^{61}$ All made their way into Bricker's speech as examples of leaders who had spent their citizens' rights as a cost of improving society. Bricker depicted a rising tide of autocracy outside the United States, which threatened to spill over into the country. The speech was a reminder that McCarthy's tirade against Dean Acheson was only one year old, and "red baiting" was on the rise.

On February 7, 1952, within a year of attacking the Covenant and with the backing of fifty-nine other Senators, Bricker introduced S.J. Res. 130, which he viewed as a more permanent solution to the threat of U.N. encroachment than modifications to individual treaties. ${ }^{62} \mathrm{He}$ meant the resolution to be a draft, something to be worked out in the halls of Congress. ${ }^{63}$ The first of its four sections asserted the supremacy of the Constitution over international agreements and treaties. The second intended to preserve the autonomy of the U.S. government by prohibiting treaties from vesting power in any international organization or government. The third section would make all treaties non-self-executing, meaning that they would require implementing legislation before having any domestic effect. And the fourth stipulated that "[e]xecutive agreements shall not be made in lieu of treaties." ${ }^{64}$

Many Senators applauded Bricker for bringing the issue before the Senate. Senator Millikin (R-CO) remarked, "I think the distinguished junior Senator from Ohio is rendering a great service to his country in focusing attention on the subject." ${ }^{65}$ Together with Senator Millikin, Senators Watkins (R-UT), Dworshak (R-ID), Kem (R-MO), and Knowland (R-CA) engaged Bricker in a Socratic dialogue, which allowed him to explain his rationale for the amendment. ${ }^{66}$

\footnotetext{
59. 82 Cong. ReC. 11511 (1951).

60. 82 Cong. ReC. $8255-56$ (1951).

61. 82 CONG. REC. 8263 (1951).

62. 82 CONG. REC. $907-09$ (1952).

63. See 82 CONG. REC. 908 (1952) (" $[N]$ o sponsor of the joint resolution claims that its language is perfect or in final form. One of the primary objectives in introducing this joint resolution is to focus attention on a grave constitutional defect and to stimulate discussion.").

64. S.J. Res. 130, 82d Cong. (1952).

65. 82 CONG. REC. 909 (1952).

66. 82 CONG. REC. 909-14 (1952).
} 
No protest or direct challenge came to S.J. Res. 130. Most Senators followed Millikin's lead or kept quiet. The issue sat on the Senate's back burner as the resolution went before the Judiciary Committee in May 1952. Outside the Senate, though, observers began to weigh in on the issue. Florence Ellinwood Allen, a Sixth Circuit judge, wrote a book on the dangers of treaty law entitled The Treaty as an Instrument of Legislation. ${ }^{67}$ She warned that the growth of "specialized agencies" within the U.N. was creating a glut of treaties that were "of a distinctly legislative character." 68 While not as politically charged as the writings of Frank Holman, Allen's work lent an air of judicial authority to the push for an amendment.

At the same time, newspapers began to take notice. The Washington Post, in two forceful editorials, deprecated S. J. Res. $130 .{ }^{69}$ One labeled it "Bricker's Shotgun" and warned of the "perils of placing the Government in a straitjacket at a time when closer international relations have become imperative to our safety." ${ }^{970}$ Unfazed and uninpressed, Bricker offhandedly dismissed the paper, saying, "1 have the following suggestion for editors of the Washington Post. In commenting editorially on any constitutional amendment, it helps to have the Constitution of the United States available for reference."."71

Discourse in the hearings before the Judiciary Committee was more polite. Frank Holman testified, as did Harvard law professor Zechariah Chafee. ${ }^{72}$ Many others-Yale law professor Myres McDougal, for example-had written work submitted to the record. ${ }^{73}$ During his testimony, Senator Bricker continued his anti-U.N., anti-International Covenant on Human Rights trope, but toned down his anti-communist rhetoric. ${ }^{74} \mathrm{~A}$ clear us-versus-them mentality, however, remained. Holman focused on the disproportionate number of communist countries in U.N. bodies, arguing that on the Commission on Human Rights, out of eighteen participating countries, fifteen were unfamiliar with "our fundamental concept of rights."75 Chafee responded with what would become a common refrain: "What is obvious from the hostility that has been expressed today toward those various international agreements is that you do not need a constitutional amendment to defeat them. ${ }^{.76}$ Such agreements could be overcome in the ratification process.

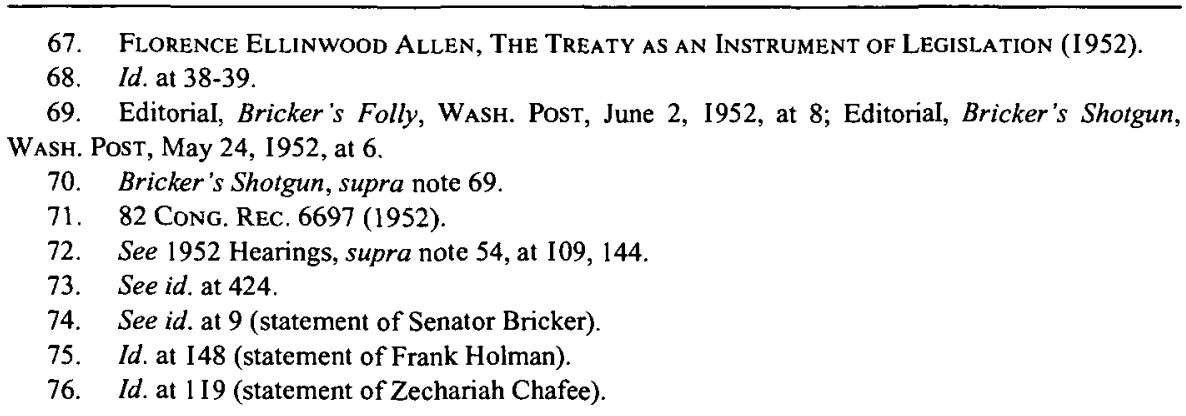


Governmental agencies and bar associations, among many groups, commented on S.J. Res. 130. The Department of Justice produced an impressively footnoted memorandum against the resolution. ${ }^{77}$ Under the auspices of Solicitor General Philip B. Perlman, the Department cautioned that it "would seriously restrict the ability of the United States to conduct foreign relations effectively." "78 Likewise the New York City Bar Association opposed the amendment, providing a counterbalance of sorts to Frank Holman's association with the $\mathrm{ABA} .{ }^{79}$ Compared with what was to come, both sides mounted very modest campaigns. The 1952 hearings lasted only five days, and much of the record consisted of submitted documents rather than live, in-person testimony. ${ }^{80}$ ln the end, S.J. Res. 130 never made it out of the Judiciary Committee.

When the Eighty-second Congress recessed, there was little or no evidence that an all-out melee was imminent. Democrat, Adlai Stevenson, had lost the 1952 election to his Republican challenger, Dwight Eisenhower. Gone were the internationalist sympathizers Secretary of State Dean Acheson and Solicitor General Philip B. Perlman. ${ }^{81}$ Instead, Eisenhower appointed treaty skeptics such as John Foster Dulles as Secretary of State. Dulles, much to the delight of Bricker and his supporters, had publicly stated that treaties were liable to abuse and could be used to alter the Constitution. ${ }^{82}$ Bricker was never over-optimistic, but going into the Eighty-third Congress, he must have been sanguine about his proposal's prospects.

\section{III}

\section{Fertile Ground for a Falling Out: Senate Joint Resolution 1 Divides REPUBLICANS}

The year 1953 proved a busy one for Senator Bricker, Frank Holman, and their supporters as S.J. Res. 1 replaced S.J. Res. 130 as the vehicle for amending the Constitution. The Senate spent many weeks debating the merits of the proposal only to have it go before the Judiciary Committee for a dense and protracted hearing, in which Senators debated points at

77. See Memorandum of the Department of Justice on S.J. Res, 130, 82d Congress Proposing an Admenment [sic] to the Constitution of the United States Relative to the Making of Treaties and Executive Agreements (June 19, 1952).

78. Id. at 39.

79. See The Association of the Bar of the City of New York, Report on "Joint Resolution Proposing an Amendment to the Constitution of the United States Relative to the Making of Treaties and Executive Agreements" (S.J. Res. 130) (May 13, 1952).

80. See 1952 Hearings, supra note 54.

81. Walter J. Cummings, Jr. was actually Truman's last Solicitor General, but it was Perlman who put up the legal arguments against S.J. Res. 130 and whom the Brickerites viewed as soft on internationalism.

82. See John Foster Dulles, Address at the Regional Meeting of the American Bar Association, Louisville, Ky. (Apr. 11, 1952), in 1953 Hearings, supra note 2, at 862-64. 
length. ${ }^{83}$ Missouri v. Holland ${ }^{84}$ still occupied center stage, but a number of other decisions by state and federal courts also received ample discussion. Bricker and Holman parted ways over a clause-later known as the "which clause"-because they could not agree on its wording and effect.

The hearings centered on two proposed amendments: Bricker's wellknown and much discussed S.J. Res. 1 and Senator Watkins's Senate Joint Resolution 43 (S.J. Res. 43). Watkins's proposal contained the controversial "which clause;" S.J. Res. 1 did not. ${ }^{85}$ The divergence of the two resolutions would only be the first of the mangrove offshoots that various senators would propose in the months and year to come.

In the meantime, the opposition shored up, bringing together the disparate interests of John Foster Dulles and Philip Perlman, the respective legal champions of the Republican and Democratic parties. Ultimately, the debates and hearings resulted in the Judiciary Committee recommending the adoption of an amendment in a polarized report notable for its confident majority and steadfast minority ${ }^{86}$

\section{A. The Split Over Semantics}

Bricker did not waste any time at the opening of the 83rd Congress, introducing his proposed amendment on January 7, 1953 in anticipation of the incoming Eisenhower Administration ${ }^{87}$ Bricker introduced his proposal before Eisenhower's inauguration to, in the words of historian Duane Tananbaum, "force the new administration's hand." 88 He hoped that Dulles's public statements on treaties, combined with the Administration's general unpreparedness to oppose an amendment sponsored by fellow Republicans, would ensure that the Administration supported S.J. Res. 1. The Administration, though in a bind, did not bow to Bricker's machinations. Instead it stalled, then gradually proceeded to cautiously oppose the amendment, engaging in some Machiavellian political tactics of its own. In 1953, the Eisenhower Administration, not wanting to ruffle the feathers of its Republican allies, was in a constant game of catch-up with the Brickerites. That hesitancy disappeared by 1954 when the battle lines drawn by the Judiciary Report became clear.

Upon submitting S.J. Res. 1, Bricker made a brief speech in which he reintroduced the underlying themes in his arguments for S.J. Res. 130. He was not, he insisted, against the U.N. per se, only its encroachments on national sovereignty: "Nothing threatens the existence of the United

83. See 1953 Hearings, supra note 2.

84. 215 U.S. $416(1920)$.

85. S.J. Res. 1 (1953); S.J. Res. 43 (1953).

86. See Judiciary Report, supra note 15.

87. S.J. Res. 1 (1953).

88. Duane Tananbaum, The Bricker amendment Controversy: A Test of Eisenhower's Political Leadership 68 (1988). 
Nations more than its desire to interfere in matters essentially within the domestic jurisdiction of its members." ${ }^{9}$ To make matters worse, the "American Communists employed by the U.N. have had a hand in advancing Communist doctrines. ${ }^{.90}$ While he did not harp on communist infiltration, Bricker did capitalize on the red malaise of the times, insuring it was an undertone of the debate.

A public discourse also emerged. Arthur Krock of the New York Times began a sustained campaign against S.J. Res. 1 in February 1953, ${ }^{91}$ and he kept tabs on it through its death throes in 1956-1957..$^{2}$ Several groups across the country aligned themselves with one side or the other as Bricker and his opponents scrambled to collect as much public support as possible. Following in the steps of the New York City Bar Association, the New York State Bar Association formally opposed the resolution at its annual meeting in January $1953 .^{93}$ In the other camp, the American Medical Association endorsed S.J. Res. I. ${ }^{94}$

Before much debate occurred, the resolution went to the Judiciary Committee. However, unlike S.J. Res. 130, which the Senate ignored while it was before the Committee, debates took place on the floor almost in tandem with the hearings. The Judiciary Committee hearings proved much more robust for S.J. Res. I than for S.J. Res. I30. Once again, Frank Holman was present. William Langer (R-ND), chairman of the Judiciary Committee, invited Holman and his ABA colleagues to sit at his table and allowed them to question witnesses. ${ }^{95}$ Holman was also one of the few people to testify twice, once early in the proceedings, and again near the end. $^{96}$ Unlike the hearings on S.J. Res. 130, several political luminaries testified at the 1953 hearings rather than submit written testimony. In addition to the usual suspects-Secretary of State Dulles, Attorney General Herbert Brownell, Jr., and former Solicitor General Perlman-several governmental agencies sent representatives. Several academics, representatives of social groups, and individual attorneys also testified.

While supporters of S.J. Res. 1 had similar motivations, they nevertheless suffered from a lack of unity. International relations scholar Natalie Hevener Kaufman has generated a typology of arguments presented by the

\footnotetext{
89. 83 CONG. REC. 161 (1953).

90. Id.

91. See Arthur Krock, The Effort to Limit 'Supremacy of Treaties, ' N.Y. Times, Feb. 26, 1953, at 24.

92. See Arthur Krock, A New Form of Bricker's 'Which' Clause, N.Y. Times, Mar. 6, 1956, at 30.

93. New York State Bar Association, Report of Committee on International Law and Discussion of Resolution (Jan. 30, 1953).

94. 1953 Hearings, supra note 2 , at 16.

95. Id. at 3, 406 .

96. Id. at $130,1216$.
} 
Brickerites in the hearings. ${ }^{97}$ According to her analysis, those in favor of the amendment presented nine basic arguments: they feared treaties could be used to diminish basic rights, violate states' rights, promote world government, subject citizens to trial abroad, threaten the U.S. form of government, enhance Soviet/communist influence, infringe on domestic jurisdiction, create self-executing obligations, and increase international entanglements. $^{98}$

Certainly, classifying the arguments helps to make sense of the more than 1,300 pages of testimony, but it misses the nuances and tensions within the camp supporting the amendment. Lumping supporters of S.J. Res. 1 and S.J. Res. 43 together is somewhat misleading. After all, if their arguments had been substantially similar, there would have only been one resolution. Even though both sides were cordial and, according to Senator Watkins, had a "unity of purpose," members of the ABA still felt strongly enough about the issue to have their version put up for consideration. ${ }^{99}$ What started as a surface crack became a fissure the following year, when the Eisenhower Administration used the "which clause" as its primary source of opposition to the Bricker Amendment.

The crux of the issue lay in section two of the proposed amendment. Senator Bricker's version stipulated, "A treaty shall become effective as internal law in the United States only through the enactment of appropriate legislation by the Congress."100 Senator Watkins's resolution was similar but had a clause that sought to vitiate Holland: "A treaty shall become effective as internal law in the United States only through legislation which would be valid in the absence of the treaty." 101 In effect, S.J. Res. 1 would make all treaties non-self-executing because Congress would have to pass implementing legislation before a treaty would take effect. S.J. Res. 43 would effectively overturn Justice Holmes's and Judge Trieber's reasoning in the Migratory Bird Treaty cases. ${ }^{102}$ Any future reading of the Supremacy Clause would have been subordinate to the Tenth Amendment under S.J. Res. 43's rubric. The two competing amendments represented a fundamental difference in conception of how to rein in executive power. S.J. Res. 1 would have kept power in the federal government, shifting it from the executive branch to Congress; S.J. Res. 43 would have devolved power to the states at the executive branch's expense.

Much later, after he acceded to the "which clause," Bricker defended the effect of the Migratory Bird Treaty. According to Bricker, had Holland come before the Court in the 1950 s, it would have been decided on the

97. Natalie Hevener Kaufman, Human Rights Treaties and the Senate 106 (1990).

98. Id. at 108-15.

99. 1953 Hearings, supra note 2 , at 15-16.

100. S.J. Res. 1, §2 (1953).

101. S.J. Res. 43, § 2 (1953) (emphasis added).

102. See supra notes $37-43$ and accompanying text. 
basis of the Commerce Clause. ${ }^{103}$ His line of thinking did not conflict with reality; the lower district court decisions ruling Congress's initial attempts to regulate migratory birds unconstitutional never made it to the Supreme Court. ${ }^{104}$ Bricker cited no specific cases, but his confidence doubtlessly derived from his understanding of Rice v. Santa Fe Elevator and Wickard $v$. Filburn. ${ }^{105}$ Wickard's broad reading of Congress's power under the Commerce Clause doubtless would have allowed for regulation of migratory birds through legislation, obviating the need for a Migratory Bird Treaty and its implementation into domestic law through the Supremacy Clause. Although subtle, Bricker's views regarding Holland suggest that he was not obsessed with states' rights. He wanted to curb executive power, not federal power. Bricker's decision to accept the "which clause" demonstrated his strong desire to limit the U.N.'s allegedly undue influence, and also his acceptance of the fact that, for better or worse, he was wedded to Frank Holman and the ABA in his quest.

\section{B. The Amendment's Opponents}

The split over the "which clause" did not prevent Bricker and Holman from presenting a unified front against the amendment's opposition. Secretary of State Dulles, Attorney General Brownell, former Solicitor General Philip Perlman, and various government agency counsels carried the weight of opposing the amendment. Dulles had the difficult task of modifying his public remarks on treaties. ${ }^{106}$ His two-pronged approach tempered conciliation with skepticism about the necessity of a constitutional amendment. Formally announcing the Eisenhower Administration's commitment to use treaties "only within traditional limits," Dulles attacked some of the U.N.'s treaties, including the Convention on the Political Rights of Women, which he cited as an example of "treaty coercion." 107 To this, he appended his doubts on the "which clause," arguing that it would "create a no-man's land in foreign affairs." 108 Rather than embroil himself personally in the finer points of the debate, he submitted three State

103. 83 CoNG. REC. 1890 (1954) ("l do not want to do damage to the migratory bird control, and we are not by the proposed amendment doing any damage . . . It was never considered by Congress, 34 years ago, that a man who operates an elcvator in a building in the Senator's State is engaged in interstate commerce. But that is the law today.").

104. See supra notes $37,40,45$, and aecompanying text.

105. Rice v. Santa Fe Elevator Corp., 31 U.S. 218 (1947) (holding that Congress may regulate warehouses that store grain for interstate or foreign commerce); Wickard v. Filburn, 317 U.S. 111 (1942) (holding that Congress may regulate grain grown for personal consuinption due to its indirect effects on national markets). Senator Bricker's comments suggest that he had Rice in mind. However, generally speaking, Wickard was the case that most broadly expanded Congress's commerce power.

106. See Dulles, supra note 82.

107. 1953 Hearings, supra note 2 , at 825 .

108. Id. at 829 . 
Department memoranda that forcefully rejected the proposed amendment. $^{109}$

Next, Dulles turned to his prior statements on treaties. He had stated that "treaty law can override the Constitution," and that " $[t]$ he treatymaking power is an extraordinary power, liable to abuse." 110 Without reversing himself, Dulles said that he had felt that way and believed that the issue should be studied, commending Bricker for his work. He added, however, that the proffered amendments were inadequate because the Framers drafted the Constitution in such a way as to account for all possibilities. He likened himself to an inexperienced painter confronted with modifying the work of a master:

If $I$ am brought in a portrait by some great artist, and 1 am asked to get my brush out and touch it up, I find I am a little hesitant about doing it. The more I have tried to draft out proposed amendments-and I have made a very honest effort to do so, because $I$ do believe that if it is possible by legal enactment to prevent abuse without depriving people of these necessary powers, that is always a good thing to do-I have not, myself, as yet been able to think of an amendment to the Constitution which would actually prevent abuses without raising very grave questions as to essential powers. ${ }^{111}$

Dulles was the most sympathetic administration official, and even he was unwilling to budge and support the amendment. His argument was wise for two reasons. First, it freed him from legalistic quibbling, in which both sides were wont to engage. Second, it pointed to a fundainental problem with the proposal: a constitutional amendment was not necessarily the solution. The "which clause" and the absence of popular support aside, Congress should have first tried to use the constitutional means open to it (e.g. the power of the purse) to check the executive's transgressions before taking the radical step of amending the Constitution. No such attempts were made. Dulles's approach, though wise, was ineffective because he did not explore the other plausible and more practical solutions. Instead, the best he offered was an abstract trust in the system and its elected officials.

Similar to Dulles's stance, Attorney General Brownell took a moderate approach to the hearings. Although he acknowledged that the amendment highlighted "a problem that deserves most serious study," he nonetheless felt strongly that the amendment was the wrong tool for the job. ${ }^{112}$ Brownell's testimony, coinbined with that of Dulles, completed the Administration's footwork to avoid stepping on the toes of amendment supporters. Attorneys from departments in the executive branch fleshed out

109. Id. at $840-53$.

110. Dulles, supra note 82 , at 862 .

111. 1953 Hearings, supra note 2, at 866 .

112. Id. at 904. 
Dulles's and Brownell's arguments. For example, Frank Nash and Roger Kent, counsels to the Defense Department, argued that the amendment would stifle the President's unimpeded ability to enter into executive agreements and negotiate treaties over military matters. ${ }^{113}$ Elbert Tuttle, general council of the Treasury Department, stressed the deleterious effects the amendment could have on narcotics control. ${ }^{114}$

Philip Perlman could not avoid the terse plucks that Dulles and Brownell so adeptly ducked. In a remarkable lack of cordiality, Frank Holman lit into Perlman, whose active role against any amendment to the Constitution had earned him Holman's ire. Perlman had turned his Justice Department memorandum ${ }^{115}$ into a law review article in an attempt to publicize his views. ${ }^{116}$ The main argument between Holman and Perlman concerned whether consensus in support of the amendment existed in the legal community, specifically the ABA's commitment. Perlman introduced into the record a report of the ABA's Section of International and Comparative Law that undermined Holman's assertion that the ABA wholeheartedly supported the amendment. ${ }^{117}$ Holman and the committee chairman, Senator Langer, refused to recognize the report, asserting that its authors had used procedural finesse to espouse views that represented neither the ABA nor the Section of International and Comparative Law. ${ }^{118}$ Regardless of the report's representative value, it demonstrated that the ABA did not unanimously favor a constitutional amendment. Holman's caviling typified the efforts of amendment supporters to present a united front, which at times devolved into a with-us-or-against-us mentality.

Mounting tensions resulted in personal attacks and political maneuvering. No one event better captured the venom of the debate than the censure of Senator Wiley (R-WI). Wiley sided with the Administration as it veered away from Bricker's plan. Just as Philip Perlman sought to chip away the movement's claim of unanimous ABA support, Wiley tried to discredit the notion that the amendment had academic support. He solicited the opinion of the deans of the nation's top law schools. ${ }^{119}$ "It is possible that this resolution will be considered by the Senate within the next few

113. See id. at 959,969 .

114. Id. at $999-1001$.

115. See Memorandum of the Department of Justice, supra note 77.

116. See Philip B. Perlman, On Amending the Treaty Power, 52 Colum. L. Rev. 825 (1952) (arguing that the Constitution's treaty power provisions are sound and that no need for changes to those provisions had been shown).

117. American Bar Association Section of International and Comparative Law, Report on the Section of International and Comparative Law of the House of Delegates on S.J. Res. 1 (83:1) (The Bricker Amendment), reprinted in 1953 Hearings, supra note 2, at 403-05.

118. 1953 Hearings, supra note 2, at 406

119. Staff of Senate Comm. on the Judiciary, 83d Cong., Proposals to Amend the Treaty-Making Provisions of the Constitution: Views of Deans and Professors of Law (Comm. Print 1953) [hereinafter Views of Deans and Professors of Law]. 
weeks," he wrote, "and I am most anxious that the Members of the Senate have before them the views of representatives of our great legal institutions as to whether the United States Constitution should be amended as proposed." 20 Out of twenty-seven deans and professors who replied, only one, R.G. Storey of Southern Methodist University's law school, lent his support. ${ }^{121}$ The rest, in varying degrees, spoke out against the amendment.

Dean Storey was not alone in embracing the amendment, but positive feelings appeared scant. The few legal scholars who supported it commanded a disproportionately large voice. They testified at a higher rate before the Judiciary Committee ${ }^{122}$ and, initially, produced more academic publications. ${ }^{123}$ Clarence Manion, one-time dean of Notre Dame's law school, allied himself with Holman and Bricker. He testified before the Judiciary Committee, telling its members that he believed the issue was "the hottest question since the Civil War." 124 However, his opinion, and those of the few other academics who backed Bricker, did not have the force of legal academia's authority.

Wiley's survey of legal academics took much wind from his supporter's sails. His efforts earned him a censure at Wisconsin's Republican Party convention. ${ }^{125}$ The censure resolution, promulgated $s u b$ rosa by unnamed delegates, said that Wiley should not seek reelection in three years. ${ }^{126}$ At the convention, attendees booed Wiley as he delivered an address, but the push to formally castigate him was not unanimous. ${ }^{127}$ For his part, Wiley thought the attacks "dastardly" and called for an FBI investigation from the Senate floor. ${ }^{128}$ Slightly embarrassed by the debacle, Wisconsin Republicans tried to wait the ordeal out. ${ }^{129}$ But Wiley sought to clear his name by submitting into the Congressional Record scores of letters he received from Wisconsin citizens who decried his censure as

120. Id. at 4 .

121. Id.

122. Of the three academics who testified, two opposed the amendment and one supported it. 1953 Hearings, supra note 2, at 1II-IV. But given the ratio of 1:26 elicited by Wiley's call for letters, see supra note $1 \mathrm{I} 9$, the $1: 2$ ratio at the hearings is significant.

123. See, e.g., Bricker, supra note 23; George A. Finch, The Need to Restrain the Treaty-Making Power of the United States Within Constitutional Limits, 48 AM. J. INT'L L. 57 (1954); Donald R. Richberg, The Bricker Amendment and the Treaty Power, 39 VA. L. Rev. 753 (1953). But see Arthur H. Dean, Amending the Treaty Power, 6 STAN. L. Rev. 589, 608-09 (1954) (pointing out practical problems with implementing an amendment); John B. Whitton \& J. Edward Fowler, Bricker Amendment-Fallacies and Dangers, 48 AM. J. INT'L L. 23 (1954) (criticizing the major arguments cited in support of the Bricker Amendment).

124. 1953 Hearings, supra note 2, at 819.

125. Wiley Denounces State G.O.P Attack, N.Y. TrmES, June 19, 1953, at 15.

126. Id.

127. Id.

128. Wiley Asks F.B.I. to Trace 'Smearer, ' N.Y. TimEs, June 25, 1953, at 18.

129. G.O.P Seeks 'Haven' Over Wiley Storm, N.Y. TIMES, June 28, 1953, at 40. 
"uncalled for and unfair." $130 \mathrm{He}$ also stepped up his criticism of the proposed amendment.

The hearings left a rift in the party. Eisenhower opposed the amendment and many Republicans were uncertain whether to side with the President or jump at the chance to shift power from the federal government to the states. The discord toned down as the Senate awaited the report of the Judiciary Committee. When the Committee issued its report in 1954, the debate reignited, with liberals and Eisenhower Republicans on one side and conservative Republicans and Southern Democrats on the other.

IV

IDEOlogies Collide: The Judiciary Report

The Judiciary Report captured both sides' legal arguments. More importantly, it documented their ideologies. On June 15, 1953, the Committee released its report recommending a modified version of S.J. Res. 1. ${ }^{131}$ Senators Jenner (R-IN), Watkins (R-UT), Hendrickson (R-NJ), Dirksen (RIL), Welker (R-ID), Butler (R-MD), McCarran (D-NV), Eastland (D-MS), Smith (D-SC), and Johnston (D-SC) formed the majority. In the minority were Senators Hennings (D-MI), Kefauver (D-TN), Kilgore (D-WV), and Wiley (R-WI). Senator Langer (R-ND) issued an individual opinion, in which he advocated not reporting the measure to the full Senate. Republicans and Southern Democrats set aside their differences and saw eye-to-eye on the benefits of reporting the amendment, most likely in an unspoken acknowledgment that the amendment would protect segregation from international interference. ${ }^{132}$ The final product more closely resembled S.J. Res. 43, the measure containing the "which clause" introduced by Senator Watkins and supported by Frank Holman, than it did Bricker's S.J. Res. $1 .{ }^{133}$

\section{A. The Majority Report}

The majority report provided a section-by-section analysis and arguments for its version of the amendment. Section 1-“[A] provision of a treaty which conflicts with this Constitution shall not be of any force or effect"- - was in many ways the least controversial part of the amendment. ${ }^{134}$ At worst, it was an innocuous addition to the Constitution and a waste of the Senate's time. At best, it limited the judiciary's ability to validate treaties, although a court determined to uphold a treaty of dubious

130. 83 Cong. Rec. A4330 (1953).

131. See Judiciary Report, supra note 15.

132. See Kaufman, supra note 97, at 109 (citing arguments by proponents of the Bricker Amendment that treaties could be uscd to legitimize federal legislation restricting segregation).

133. Judiciary Report, supra note 15, at 36.

134. Id. at 3 . 
constitutionality might nevertheless uphold the treaty even with Section 1 in the Constitution.

To the majority's mind, the first section pitted nineteenth-century precedent against that of the first half of the twentieth century. ${ }^{135}$ In fact, the basic premise of the section had been memorialized time and again by the Supreme Court in the 1800s. In Doe v. Braden, the Court clearly stated: "The treaty is therefore a law made by the proper authority, and the courts of justice have no right to annul or disregard any of its provisions, unless they violate the Constitution." ${ }^{136}$ Contrasted with this precedent, the majority of the committee read Missouri v. Holland as holding that "the treatymaking power was not limited by the 10 th amendment"137 and therefore abandoning the Court's nineteenth-century trend. Retired Chief Justice Charles Evans Hughes bolstered this outlook, telling the American Society of International Law, "I should not care to voice any opinion as to an implied limitation on the treaty-making power. The Supreme Court has expressed a doubt whether there could be any."138 The Court's decisions in United States v. Curtiss-Wright Export Corp. ${ }^{139}$ and the Steel Seizure Cases $^{140}$ solidified this view.

Holland and Curtiss-Wright were the primary sources of concern for the majority, which feared the decisions leaned heavily toward "an unlimited treaty power." "141 As discussed previously, Holland heId implementing legislation of a treaty constitutional even if similar Congressional action in the absence of the treaty would not be. ${ }^{142}$ Curtiss-Wright, while not dealing explicitly with treaties, unequivocally named the executive as the nation's voice in international affairs. ${ }^{143}$ Specifically, the Court heId that the President could determine the international effect of congressional resolutions dealing with foreign affairs. ${ }^{144}$

135. See id. at 3-8.

136. 16 How. 635, 657 (I853); see also Geofroy v. Riggs, 133 U.S. 258, 267 (1890) ("It would not be contended that [the treaty power] extends so far as to authorize what the Constitution forbids, or a change in the character of the government."); Hauenstein v. Lynham, 10 U.S. 483, 490 (1880) ("There are doubtless limitations of [the treaty] power as there are of all others arising under such instruments."); The Cherokee Tobacco Case, I1 Wall. 616, 620-21 (1870) ("It nced hardly be said that a treaty cannot change the Constitution or be held valid if it be in violation of that instrument.").

137. Judiciary Report, supra note 15, at 4.

138. Charles E. Hughes, Address at American Society of International Law Twenty-Third Annual Meeting (Apr. 24, 1929).

139. 299 U.S. 304 (1936).

140. Youngstown Sheet \& Tube Co. v. Sawyer, 343 U.S. 569 (1952).

141. Judiciary Report, supra note 15, at 7.

142. See supra notes $40-48$ and accompanying text.

143. 299 U.S. 304,319 (1936) ("[T]he President alone has the power to speak or listen as a representative of the nation. He makes treaties with the advice and consent of the Senate; but he alone negotiates. Into the field of negotiation the Senate cannot intrude; and Congress itself is powerless to invade it." (emphasis in original)).

144. Id, at 332-33. 
Section 1, the Committee determined, was unassailable because it represented "what most of the American people have always felt the law should be." 145 Section 2 , by contrast, presented more of a quagmire. 1t provided that "a treaty shall become effective as internal law in the United States only through legislation which would be valid in the absence of treaty," favoring Holman's language over Bricker's. ${ }^{146}$ The Section's intended effect - to make all treaties non-self-executing-would have increased Congress's power by requiring it to pass implementing legislation before any treaty could be legally enforced.

A source of uncertainty lay in the potentially artificial distinction between self-executing and non-self-executing treaties, the concept being a somewhat unique beast of American law. Chief Justice Marshall developed the distinction in Foster $v$. Neilson, in which he held that some treaties, by their language, required implementing legislation from Congress to be effective. ${ }^{147}$ Four years later, the case returned to the Court as United States v. Percheman, in which the Court overruled itself, holding that the treaty in question had in fact been self-executing and thus required no act of Congress to becoine effective. ${ }^{148}$ Despite the reversal, the distinction stuck, and it filled the majority with trepidation.

Against the backdrop of a growing number of civil rights claims in federal courts, the United States' relationship with the U.N. proved to be another major source of the Committee's angst. Several civil rights cases made Committee members uncomfortable because activists often asserted claims based on U.N. obligations. Even worse for the Committee members was the fact that some judges seemed to be listening. In Shelly $v$. Kraemer, ${ }^{149}$ a landmark case holding racially restrictive covenants unconstitutional, the American Association for the United Nations asserted that portions of the U.N. Charter dealing with human rights were selfexecuting. Two other cases, Oyama v. California ${ }^{150}$ and Fujii $v$. California, ${ }^{151}$ triggered considerable concern. In Oyama, two concurring

145. Judiciary Report, supra note 15 , at 7 .

146. Id. at 8. Inferring that this was a concession to the Southern Democrats on the Committee is not too farfetched, especially given the substantially different implications of Senator Watkins's wording for states' rights. See supra notes 98-100 and accompanying text.

147. 2 Pet. 253 (1829) ("[W]hen the terms of the stipulation import a contract, when either of the parties engages to perform a particular act, the treaty addresses itself to the political, not the judicial department; and the legislature must execute the contract before it can become a rule for the Court.").

148. 7 Pet. 51 (1833). There were two versions of the treaty, one English and one Spanish. In Foster, the Court used the English version. Upon analysis of the Spanish version in Percheman, the Court determined that the treaty was in fact self-executing. Id. at 89 "We did not suppose that there was even a formal difference of expression in the same instrument, drawn up in the language of each party. Had this circumstance been known, we believe it would have produced the construction which we now give to the article.").

149. 334 U.S. 1 (1948).

150. 332 U.S. 633 (1948).

151. 217 P.2d 481 (1950), rev'd, 38 Cal. 2 d 718 (1952). 
justices argued that the United States had a moral commitment to uphold its obligations to the U.N. Charter. ${ }^{152}$ Fujii proved even more problematic. A state appellate court determined that the U.N. Charter was selfexecuting, and although the California Supreme Court overturned the lower court, it upheld one of the propositions that the Committee feared: "A treaty... does not automatically supersede local laws which are inconsistent with it unless the treaty provisions are self-executing." 153 Though the language was not exactly analogous-"local laws" being different and possibly distinguishable from constitutional mandate - the threat that a treaty could supersede the Constitution was still alive in the Committee members' minds. The majority's goal was to "make all treaties non-self-executing, so far as domestic law is concerned, until Congress acts, but the treaty will continue to be effective as an international obligation." 154

By making all treaties non-self-executing, the majority hoped that judges, like the concurring justices in Oyama and the state court in Fujii, would never be able to impose their idiosyncratic views on the country by relying on broadly-worded treaties. Its members recognized that amending the Constitution appeared extreme, but they believed the measure justified. They feared that activists would successfully maintain that the U.N. Charter gave Congress "the authority to legislate with respect to social, economic, cultural, civil, and political rights."15s The majority believed that by imposing on Congress a duty to pass implementing legislation, the resulting legislative records could be used to determine the meaning of vague treaty clauses. ${ }^{156}$ Moreover, the meaning would be generated by Congress, not the courts.

Section 3 of the proposed amendment targeted executive agreements. It stated, "Congress shall have power to regulate all executive and other agreements with any foreign power or international organization. All such agreements shall be subject to the limitations imposed on treaties by this article." 157 This section focused on the growth in executive power resulting from America's victory in World War II and its new role as self-anointed leader of the free world. Although presidents had used executive

152. 332 U.S. at 649-50 (Murphy, J., concurring) ("[W]e have recently pledged ourselves to cooperate with the United Nations to 'promote... universal respect for, and observance of, human rights and fundamental freedoms for all without distinction as to race, sex, language, or religion.' How can this nation be faithful to this international pledge if state laws which bar land ownership and occupancy by aliens on account of race are permitted to be enforced?" (internal citation omitted)).

153. $38 \mathrm{Cal} .2 \mathrm{~d}$ at 721 .

154. Judiciary Report, supra note 15 , at 11.

155. Id. at 14 .

156. Id. at 11. Here, I am referring to the following sentence: "Congress would be able to translate in the light of hearings, committee discussion, and floor debate, the generally vague provisions of a treaty into a statute stating the rights of individuals with some degree of precision."

157. Id. at 24 . 
agreements for some time, the amendment painted the Roosevelt and Truman administrations as abusers of the power. Curtiss-Wright and two cases dealing with the so-called Litvinov Assignment, United States $v$. Belmont ${ }^{158}$ and United States $v$. Pink, ${ }^{159}$ troubled members of the majority. In addition, other equally disconcerting actions never made it before the courts. Many members of Congress, especially Republicans and staunch anti-communists, were infuriated by the Yalta and Potsdam agreements that Roosevelt had signed with Britain and Russia. It was widely believed that Roosevelt had "ceded" Poland, among other areas, to Russia, thus condemning millions to a communist fate. ${ }^{160}$

Section 3 represented a scramble by some Senators to reclaim a power that Congress had allowed to bloat in the hands of the executive. Secretary of State Dulles, while testifying before the Committee, had stressed "friendly cooperation" between the President and Congress when it came to executive agreements. ${ }^{161}$ Pointing out that Congress had been left out of the loop on many of the decisions, the majority argued, "[i]t should be readily recognized that the 'friendly cooperation' which has been urged upon the committee is hardly possible if the President alone has the unlimited discretion to decide whether a particular international agreement requires the approval of one, both, or neither of the two Houses of Congress." " 62

The Supreme Court's willingness to uphold executive agreements reinforced the majority's desire to rein in executive power. The Belmont and Pink Courts asserted the primacy of the executive's prerogative in negotiating and implementing international agreements. Both decisions increased the federal government's interest in adjudicating property disputes within its borders, traditionally a practice reserved to state courts. To reach this result, the Court determined that executive agreements had the same status as treaties. Justice William Douglas, writing for the majority in Pink, held, "A treaty is a 'Law of the Land' under the supremacy clause of the Constitution. Such international compacts and agreements as the Litvinov Assignment have a similar dignity." ${ }^{63}$ His opinion accorded with Justice Sutherland's holding in Belmont. ${ }^{164}$ The majority report of the Judiciary

\footnotetext{
158. 301 U.S. 324 (1937).

159. 315 U.S. 203 (1942).

160. See Judiciary Report, supra note 15, at 26.

161. 1953 Hearings, supra note 2, at 828 .

162. Judiciary Report, supra note 15 , at 28 .

163. 315 U.S. at 230 (internal citations omitted).

164. 301 U.S. at 330-31. The majority in Belmont emphasized the independence of the executive in executing international compacts:

A treaty signifies "a compact made between two or more independent nations with a view to the public welfare." But an international compact, as this was, is not always a treaty which requires the participation of the Senate. There are many such compacts, of which a protocol, a modus vivendi, a postal convention, and agreements like that now under consideration are illustrations. The distinction was pointed out by this court in the Altman case, which arose
} 
Committee strongly urged the inclusion of Congress in decision-making of this scale, arguing that Pink "expanded the executive-agreement-making power in the same way that Missouri v. Holland... expanded the treatymaking power." 165

With its arguments for each of the three sections out of the way, the majority report discussed the urgency of the matter and its rationale for refusing to wait and undertake a more extensive study of treaties and executive agreements. Conspicuously absent from its analysis was a structured, coherent discussion of the differences between S.J. Res. 1 and S.J. Res. 43. In the end, Bricker and Holman united despite their differences, and the majority accepted that union without much discussion about the difference between the two proposals. Its discussion of the "which clause" was its only nod to the fact that it had more than one resolution to consider. Interestingly, the Committee's recommendation bore the title, S.J. Res. 1, perhaps, as some Senators suggested, to filch the gravitas of the sixty-plus senators who signed S.J. Res. $1 .^{166}$ In contrast, Senator Watkins's S.J. Res. 43 had only his name affixed to it. ${ }^{167}$

\section{B. The Minority Report}

The minority responded with similarly weighty arguments. It spent less time disputing technicalities of the legal record and more time on policy. Whereas the majority interwove S.J. Res. 1 and S.J. Res. 43, the minority report meticulously tracked the differences between the two. It also played up the Administration's discreet refusal to support a constitutional amendment, the general difficulty of amending the Constitution, and the need for a strong executive in the international arena.

Regarding Section 1, the minority stressed that treaties were on parity with federal law, and thus could not supersede or in any way modify the Constitution. ${ }^{168}$ Moreover, international law might invalidate the amendment: "Under these rules, sovereign states are bound by their solemn contracts, which have been concluded and ratified according to the normal rules of procedure, whether or not the treaties conflict with some internal law." 169 Section 1 was the least defensible but also the least assailable.

under $\S 3$ of the Tariff Act of 1897 , authorizing the President to conclude commercial agreements with foreign countries in certain specified matters. We held that although this might not be a treaty requiring ratification by the Senate, it was a compact negotiated and proclaimed under the authority of the President, and as such was a "treaty" within the meaning of the Circuit Court of Appeals Act, the construction of which might be reviewed upon direct appeal to this court.

Id. (internal citations omitted).

165. Judiciary Report, supra note 15, at 31 .

166. See 83 CoNG. REC. 657 (1954).

167. See id.

168. See Judiciary Report, supra note 15, at 40.

169. Id. at 41 . 
Essentially, it boiled down to whether or not the Supremacy Clause limited treaties. Those in the minority thought it did; those in the majority thought it did not.

The minority argued that Section 2 would destroy the global parity that the United States enjoyed with other nations with respect to treatymaking, thereby limiting national sovereiguty and jeopardizing the country's ability to enter peace agreements. Reciprocity with other nations appeared particularly at stake. For example, courts had repeatedly held that aliens in the United States enjoyed privileges guaranteed by treaties of reciprocity, even if they were prohibited by states. ${ }^{170}$ Any benefits that accrued to the United States through these reciprocal agreements would be lost if the "which clause" made its way into the Constitution, argued the minority. ${ }^{171}$

The restrictions in Section 3 on executive agreements also worried the minority, which feared that such limitations would leave the executive impotent to effectuate the United States' interests abroad and weaken national defense by diminishing the President's ability to act as commander-mchief. Furthermore, the minority bristled at the idea that executive agreements should be treated like treaties, especially because executive agreements were an amalgam of the President's implicit foreign affairs power and his explicit treaty power. The sheer number of executive agreements made the prospect of treaty-like treatment unpalatable, and in practice, many agreements were neither amenable to congressional supervision nor worth Congress's attention. Ultimately, the minority questioned the wisdom of having such a far-reaching, all-inclusive amendment that would constrain all executive agreements. ${ }^{172}$

\section{1954 Debates and the Vote}

Senator Bricker was the first to comment on the Committee's report. He decried the minority's "deliberately misleading statements," "ignorance of the law," and logical inconsistencies. ${ }^{173}$ His tirade foreshadowed the tone of the debates to come; ill will and lack of unity threatened to overwhelm the amendment, which had already been through many incarnations-S.J. Res. 130, S.J. Res. 1, S.J. Res. 43, and now, the Committee's S.J. Res. 1.

In July 1953, Senator Knowland issued a substitute version of the amendment, endorsed by the Eisenhower Administration. ${ }^{174}$ In 1954, Senator George (R-GA) submitted another substitute, followed by a

170. See Chirac v. Chirac, 2 Wheat. 259 (1817); Hauenstein v. Lynham, 100 U.S. 483 (1880); Asakura v. Seattle, 265 U.S. 332 (1924); Santovincenzo v. Egan, 284 U.S. 30 (1931).

171. See Judiciary Report, supra note 15 , at $45-47$.

172. Id. at 49-53.

173. 83 CONG. REC. 8193 (1953).

174. See Tananbaum, supra note 88 , at 109. For a full text of the Knowland-Eisenhower Administration substitute, see $i d$. app. G, at 224. 
tentative compromise between Bricker and Attorney General Brownell, and separate proposals by Senator Knowland and Bricker himself. ${ }^{175}$ The multiplicity of versions led Senator Henning (D-MO) to declare, "If, finally, a compromise is put before the Senate, it will inevitably be a hodgepodge of vague language which has a different meaning for each person who has a hand in it."176

Much of the 1954 debates amounted to a ruminative chewing of the legal cud first ingested in the Judiciary Report. For example, Senators never agreed on the appropriate scope of congressional power. Senator McCarran envisioned Congress as "a legislature of limited and delegated powers." "177 But other Senators felt that Congress's authority should expand, having been unfairly restricted by the President's grab for power. Senator Bridges claimed, "Never in the history of the United States has a President acted with such disregard of the Constitution, the law, and the will of Congress." 178 Bricker agreed, griping about Eisenhower's involvement in the Senate deliberations on S.J. Res. I and its progeny. He thought the President should avoid infringing on Congress's prerogative to develop and debate constitutional amendments. ${ }^{179}$

To the Brickerites, the "one-worlders" and communists constituted an even more pernicious influence. Bricker believed that those in favor of a world government had hijacked the U.N. and tainted its purpose so much that the United States had to defend itself from U.N. assaults originating internationally and domestically. In February 1954, he introduced a list of one-worlders who had opposed the amendment, giving their names and organizational affiliations. ${ }^{180}$ This list of individuals who impliedly opposed the U.S. government-or at least favored a much weakened onesmacked of McCarthyism, though it lacked the invidious barbs and iniquity of McCarthy's imquisition.

The Senate debates reached a nadir of comity shortly after Bricker introduced his list, when Senator Jenner (R-IN) made a vitriolic speech on the Senate floor decrying the influence of a "secret revolutionary corps" of communists and socialists within the government, who "understand[] well

175. For the various dates and wordings of the numerous substitutes, see $i d$. apps. C-K, at 222-26.

176. 83 CONG. REC. 1205 (1954); see also 83 CoNG. REC. 1762 (statement of Senator Morse) ("[W]ithout the advantage of having a report by the Judiciary Committee, following a hearing held by it, on the meaning of the Ferguson-Knowland amendment ... [it is] not safe for us to pass on to the American people a recommendation for a constitutional amendment.").

177. 83 CONG. ReC. 934 (1954).

178. 82 CONG. REC. 4013 (1952). This view is harder to pin down than the states' rights arguments because most Republicans would not argue explicitly for anything that would expand federal power in any branch. However, examples emerge in the course of the debate. For instance, Bricker's support for the goal of the Migratory Bird Treaty Act, and to some extent his legal argument against it, were premised on his belief in the Senate's expansive power.

179. Id.

180. 83 CONG. REC. 1419 (1953). 
the power to influence the people about them, by praise and fear, and by creating a climate of opinion, by an elegant form of brainwashing, which convinces their coworkers of policies and slanted opinions they would never have chosen in the free air." 181 Opponents of the amendment did their best to sidestep such caustic assertions. Flipping the rhetoric on Jenner and his ilk, Senator Wily attributed to them the status of a "small minority" of propagandists who had a disproportionate influence on the debate. ${ }^{182}$

Both sides wrote off the extremism of the other, focusing instead on voters. It was easy for the Senators, a group inured to rhetorical manipulation, to ignore the untoward techniques. There is little evidence that the polarizing comments changed senators' minds. The public, however, was a different matter. Both sides expended considerable effort trying to change public opinion. Frank Holman's mass-market paperback, Story of the Bricker Amendment, promised on its jacket to be "the most important constitutional document of our time." ${ }^{183}$ Needless to say, history has borne out the exaggeration of the assertion, but it is unclear how many people read and were influenced by its partisan wrangling. Senator Wiley marveled at the 500,000 copies of a pro-Bricker Amendment pamphlet entitled "You?-In a Foreign Prison" that the Committee for Constitutional Government (the same publisher of Holman's book) disseminated. ${ }^{184}$

Claims of widespread public interest in the amendment accompanied the broad distribution of propaganda. Senator Bricker, a perennial optimist, claimed exuberant support for his amendment. At one point, he announced that he had received approximately 500,000 letters in support of his amendment. ${ }^{185}$ At another, a 500-strong association known as Vigilant Women for the Bricker Amendment presented a petition signed by 200,000 people favoring an amendment. ${ }^{186}$ More than the numbers, it was the accompanying ceremony that captured the distinct mindset of many of the amendment's supporters; in a ritualistic public display, three of the women adorned themselves in the petition. ${ }^{187}$

Both sides introduced volumes of letters into the record. In keeping with his proclivity for epistolary support, Senator Wiley led the movement to use constituent letters to bolster his arguments. Most were fairly generic, including workaday comments of encouragement. For example, one woman told Wiley, "I wish to express my sincere appreciation for your leadership in opposition to the Bricker Amendment. Such an amendment would seriously hamper the conduct of our foreign affairs by the executive

\footnotetext{
181. 83 CoNG. REC. 2122 (1954).

182. 83 Cong. ReC. 1235 (1954).

183. See Holman, supra note 1 , inside jacket.

184. 83 CONG. REC. 1235 (1954).

185. 83 CONG REC. 779 (1954).

186. James Reston, 'Vigilant Women' Endorse Bricker, N.Y. TimEs, Jan. 26, 1954, at 14.

187. Id. The article contains a photograph of three women draped in the petition.
} 
in an age when continuing efforts toward international cooperation are so extremely important." ${ }^{188}$ In and of itself, the letter was relatively meaningless. But when joined with the sea of other letters introduced into the record, it proved a force to be reckoned with. Bricker's claims of having received thousands of letters may have sounded impressive, but in the record, his words took up less than a line.

Boasts of popular support based on the number of letters received were mostly grandstanding. Just as he undercut Bricker's assertion that he had the support of legal academics, Wiley deflated Bricker's claims that widespread popular support existed for an amendment. An October 6, 1953, Gallup poll that Wiley introduced into the record showed that $81 \%$ of those polled had never heard of the amendment; of those who had, $9 \%$ were in favor, $7 \%$ opposed, and $3 \%$ had no opinion. ${ }^{189}$ A second poll, taken on January 26,1954 , that Wiley introduced into the record determined that out of those polled, $72 \%$ had not heard of the amendment. The gain did not help the Brickerites. Of the $28 \%$ familiar with the amendment, only $13 \%$ could give a "reasonably correct" statement of the amendment's provisions; of that $13 \%, 4 \%$ favored it, with $7 \%$ opposing it and the remaining $2 \%$ uncertain. ${ }^{190}$ In a battle of numbers, the Gallup polls leant credence to the opposition's view that a small minority was foisting its constitutional vision on the rest of the country. And even that vision was not unified.

More than anything else, divisions amongst the amendment's supporters caused its downfall. Not all who introduced substitute or perfecting amendments intended their contributions to enhance the debate. In fact, ample evidence shows that thc Eisenhower Administration encouraged substitute proliferation as a means of sabotaging the pro-amendment camp's support. ${ }^{191}$ With the vote approaching, three substitute or perfecting amendments came before the Senate: the Administration-backed Knowland-Ferguson proposal, the George proposal, and the Bricker proposal. The Knowland-Ferguson amendment was a paper tiger that would have done nothing to change the status quo. Senator George's proposal only targeted executive agreements for more congressional supervision. And Bricker's perfecting amendment scrapped the "which clause" in favor of a less controversial approach that was more likely to win support. ${ }^{192}$ Much squabbling ensued as a result of the different points of view.

188. Letter from Mrs. Arnold Goodman to Senator Alexander Wiley (Jan. 18, 1954) (reprinted in 83 Cong. ReC. 929 (1954)).

189. George Gallup, Nine Percent Favor Bricker Amendment, Seven Percent Oppose It, Oct. 6, 1953 (reprinted in 83 Cong. Rec. 672 (1954)).

190. George Gallup, Gallup Poll-Bricker Amendment Chances Appear to be Slim in States, Wash. Post, Jan. 27, 1954 (reprinted in 83 Cong. Rec. 860-61 (1954)).

191. See Tananbaum, supra note 88 , at 156 ("Eisenhower had reluctantly endorsed the Knowland-Ferguson amendment to try to ward off the more stringent measures.").

192. See Cong. Rec. 2042 (1954) (presenting a list presented to the Senate giving the wording of each proposal). 
Bricker was aware of the danger to his vision. In the face of pressure to adopt the Administration-sponsored version, or George's executiveagreement-only substitute, he stood fast, maintaining that "[a]ny attempt to sell a watered-down substitute ... could only be described as an effort to defeat its fundamental purpose." 193 Nevertheless, the damage was done. Many on the Senate floor were tired of the debate. Eruptions of "Vote! Vote!" peppered the debates as senators tried to close the discussion. ${ }^{194}$ Bricker's amendment lite, absent the "which clause," went down by a vote of 42 yeas to 50 nays. ${ }^{195}$ With that vote, Bricker's push to amend the Constitution came as close as it ever would. Dilution and vigorous bipartisan opposition combined with the stringent standards of passing a constitutional amendment to drag down Bricker's dream. Still, a vote of 42-to-50, in spite of those daunting impediments, hints that Bricker touched a political nerve.

A much more interesting tale played out in Senator George's substitute. Much shorter than the other proposals, George's substitute amendment had two sections. The first read: "A provision of a treaty or other international agreement which conflicts with this Constitution shall not be of any force or effect." The language was not novel or controversial, as all the amendments had some language to similar effect. Section two stated: "An international agreement other than a treaty shall become effective as internal law in the United States only by an act of Congress."196 This section was also neither novel nor controversial; if anything, Senator Bricker's assertion that it was "watered-down" with respect to what he originally wanted was spot on. ${ }^{197}$ But its popularity suggested that more senators were comfortable with the "watered-down" version.

In somewhat bizarre circumstances, George's substitute failed Senate endorsement by only one vote, with a final tally of 60 yeas to 31 nays. ${ }^{198}$ For a few moments, it appeared that it had passed, but sensing a loss, the opposition acted. Senator Kilgore (D-WV), who opposed an amendment in any form, reportedly was drinking in a bar during the debates. When the opposition members saw that their prospects were looking poor, they went and rousted him, bringing him to the Senate. Swooping in, an inebriated deus ex machina, he cast the final vote and narrowly prevented the George amendment's passage. Solne question remained as to whether Kilgore

\footnotetext{
193. 83 CoNG. ReC. 2133 (1954).

194. 83 CONG. REC. 1916, 2256, 2261 (1954).

195. 83 CONG. REC. 2262 (1954).

196. Cong. Rec. 2042 (1954). This section would, in effect, make all executive agreements nonself-executing; they would be valid as international law, but would have no effect on domestic U.S. law. Essentially, they would be governed by the same rules as treaties.

197. See supra note 193.

198. 83 CONG. REC. 2374-77 (1954).
} 
himself actually cast the vote or another senator cast it for him. ${ }^{199}$ Ultimately, it did not matter; the measure was defeated.

The two sets of votes were the closest the Senate came to amending the Constitution. If one of them had passed, it would still have had to go through the House of Representatives for two-thirds approval and be ratified by three-fourths of the state legislatures. ${ }^{200}$ It is difficult to determine how Bricker's or George's proposal would have fared had they made it out of the Senate, but Bricker seemed determined to find out.

Bricker pushed on, but would never regain the level of support that he once had. In 1955, the Judiciary Committee held another set of hearings. ${ }^{201}$ These consisted mostly of recapitulated arguments and were not nearly as robust as the I953 hearings. Like the I952 hearings, the 1955 hearings consisted primarily of written submissions, with no votes or extensive debates. ${ }^{202}$ Spending so much time pushing for an amendment turned Bricker into a one-trick pony. Once immensely popular, he lost his 1958 bid for reelection after winning easily in 1946 and $1952 .{ }^{203}$ The initial thrust provided by the Senate Judiciary Committee's endorsement of S.J. Res. I fizzled, and Bricker's quest ended in ignominy.

$\mathrm{V}$

The Bricker Controversy Today: Rethinking the Power of the EXECUTIVE IN FOREIGN AFFAIRS

The Bricker Amendment controversy offers several valuable lessons, both historical and legal in nature. An examination of the issues that arose in early Cold War America may prove instructive today because of the many similarities that period shares with the present: international politics infused with fear of a malicious, unknown adversary and a Congress and a Supreme Court unwilling to challenge the executive head-on. Institutional arguments, which justify branches of government filling in constitutional gaps based on their pragmatic ability to do so, support the status quo. However, they fail to recognize that the status quo may not be in the best interests of the country and that institutional competencies and incompetencies may be a result of prolonged exposure to changes never considered in the Framers' original balancing of powers between the branches.

199. See TAnanbaum, supra note 88 , at 180 ; Treaty-Making Power, N.Y. Times, Jan. 28,1954 , at E8.

200. See U.S. ConsT. art. V.

201. Treaties and Executive Agreements: Hearings Before a Subcomm. of the Judiciary of the United States Senate, 84th Cong. (1955) [hereinafter 1955 Hearings].

202. See id.

203. See TANANBaUm, supra note 88 , at 214-15. 


\section{A. Institutional Arguments for Executive Predominance in Foreign Affairs}

The executive has strong institutional advantages over the other two branches. Many scholars feel Congress simply cannot respond the same way that the President can to foreign threats. Harold Koh identifies this as "a pervasive national perception that the presidency must act swiftly and secretly to respond to fast-moving international events. ${ }^{.204} \mathrm{He}$ also identifies institutional reasons: legislative myopia, inadequate drafting, ineffective legislative tools, and institutional lack of political will. ${ }^{205}$ Essentially, Congress is too deliberative a body beholden to too many divergent interests. With responsibility to smaller constituencies, more allegiance to special interest groups, and the constant need to compromise, Congress consistently finds itself outmaneuvered by the President.

Eisenhower's manipulation of the Bricker controversy exemplifies the trend. By implementing dilatory tactics and playing off divisions in the Senate, he escaped the controversy unscathed while assuring the demise of any constitutional amendment that threatened the President's predominance in foreign affairs. The debate was about more than politics. It was about power, as Eisenhower and Truman's opposition attest. The alternate amendments introduced by Senators Knowland and George were little more than disguised presidential meddling. In a clear imbalance of the branches' abilities to check one another, in-fighting among senators enabled the Eisenhower Administration, with only minimal effort, to derail the amendment.

Institutionally speaking, the judiciary is little better equipped than Congress to handle foreign affairs. Julian $\mathrm{Ku}$ and John Yoo, in examining the Alien Tort Statute, make a functional argument for the predominance of the executive over the courts in determining how the statute should be applied. ${ }^{206}$ The Justice Department's Office of Legal Counsel (OLC) has the competence to handle foreign affairs matters generally, and Alien Tort Statute matters in particular, that the courts do not have. ${ }^{207}$ Specifically: "Judges are not chosen because of any background in specific regions or areas, nor are they selected because they have experience in national security issues. As an institution, the judiciary is unlikely to have great facility with international legal, political, or economic theories or materials." ${ }^{208}$ The executive branch, by contrast, has a surplus of knowledge and experience in the OLC and the State Department.

204. Harold Honguu Koh, The National Security Constitution 122 (1990).

205. Id. at 123 .

206. Julian Ku \& John Yoo, Beyond Formalism in Foreign Affairs: A Functional Approach to the Alien Tort Statute, SUP. CT. REv. 20-33 (forthcoming 2005), available at http://ssm.com/ abstract $=652141$.

207. Id.

208. Id. at 24-25. 
H. Jefferson Powell has posited that the Supreme Court has all but ceded the creation of a foreign affairs and national security legal framework to the OLC. ${ }^{209}$ Indeed, he goes so far as to assert that OLC legal opinions, not Supreme Court opinions, are the first sources the executive branch looks to when researching foreign affairs and national security law. ${ }^{210}$ Another set of John Yoo's writings support the validity of Powell's claim: the infamous memos declaring enemy combatants outside the protection of the Geneva Conventions." Memos," 212 the expanding practice of "extraordinary rendition," 13 and the current Administration's blasé response to the Supreme Court's ruling that prisoners held at Guantanamo Bay are entitled to judicial access, ${ }^{214}$ have brought peculiar focus to the weight and seriousness of the OLC's legal authority.

In the realm of foreign affairs, the Court has written off its obligation, claimed in Marbury, ${ }^{215}$ as the authoritative interpreter of the Constitution. While it may have reviewed some of the legal premises put forth in the above-mentioned OLC opinions, it has not curbed the OLC's claim to power over foreign affairs. The Court is more than capable of challenging the President. It has the power to send messages to the President, but it has done so only in two narrow contexts: when U.S. citizens are labeled enemy combatants (Hamdi v. Rumsfeld ) ${ }^{216}$ and when prisoners are held in U.S. facilities (Rasul v. Bush). ${ }^{217}$ The Hamdi and Rasul decisions, which amount

209. H. Jefferson Powell, The President's Authority Over Foreign Affairs: An Executive Branch Perspective, 67 GEO. WASH. L. REV. 527, 537 (1999).

210. Id. at 536.

211. Memorandum Opinion for the Deputy Counsel to The President (Sept. 25, 2001) http://www.usdoj.gov/olc/warpowers925.htm; see also Letter From William H. Taft IV, Legal Advisor, Department of State, to John C. Yoo, Deputy Assistant Attorney General, Office of Legal Counsel (Jan. 11, 2002); Letter from John C. Yoo, Deputy Assistant Attorney General, Office of Legal Counsel, to William H. Taft IV, Legal Advisor, Department of State (Jan. 14, 2002).

212. Memorandum for Alberto R. Gonzales, Counsel to the President Re: Standards of Conduct for Interrogation under 18 U.S.C. SS 2340-2340A (Aug. 1, 2002) available at http:/www.washingtonpost.com/wp-srv/nation/documents/dojinterrogationmemo20020801.pdf (setting the threshold of torture at pain equivalent to that accompanying "serious physical injury, such as organ failure, impairment of bodily function or even death"); Memorandum for Alberto R. Gonzales, Counsel to the President \& William J. Haynes 11, General Counsel of the Department, from Jay S. Bybee, Assistant Attomey General, Re: Application of Treaties and Laws to al Qaeda and Taliban Detainees (Jan. 22, 2002), available at http:/www.washingtonpost.com/wp-srv/nation/documents/ 012202 bybee.pdf (describing effects of international treaties and federal laws on those detained by the United States in the Afghanistan conflict); see also David Johnston and James Risen, The Interrogations: Aides Say Memo Backed Coercion Already in Use, N.Y. T1MES, June 27, 2004, at 1 (describing circumstances around the memo of August 1 and its release).

213. For an explanation of the practice, see Jane Mayer, Outsourcing Torture, NEw Yorker, Feb.

14, 2005, at 106, available at http://www.newyorker.com/fact/content/articles/050214fa_fact6.

214. Rasul v. Bush, 2004 U.S. LEXIS 4760 (2004).

215. Marbury v. Madison, 5 U.S. (1 Cranch) 137 (1803).

216. See Hamdi v. Rumsfeld, 2004 U.S. LEXIS 4761 at *2645 (plurality).

217. See Rasul, 2004 U.S. LEXIS 4760, at *2690-93. 
to piecemeal restraints on the President's freedom to act, accord with the Court's general failure to check the executive's use of power abroad.

The Court's two seminal foreign affairs cases, the Steel Seizure Cases $^{218}$ and Curtiss-Wright, ${ }^{219}$ diverge enough in their holdings to allow the executive tremendous leeway in determining the scope of his foreign affairs powers. The Steel Seizure Cases are particularly weak because the recognized law comes not from Justice Black's majority opinion, but from Justice Jackson's concurrence. In it, he defined three zones of Presidential power that provide a framework for analyzing executive actions on their face, but do little to constrain his actions in practice. The first zone, where the President acts with the backing of Congress, is rarely the source of controversy. It is in the second and third zones that the executive can take advantage of the ambiguities of the foreign affairs power. For example, response to President Bush's treatment of enemy combatants was so muted as not to constitute a challenge in terms of Justice Jackson's third category: when the President acts against the "express or implied will of Congress."220 Therefore, he was not considered to be at the "lowest ebb"221 of his presidential powers. Rather, he was perceived to be somewhere in the second zone, where the President acts "in absence of either a congressional grant or denial of authority," and as a result must "depend on the imperatives of events and contemporary imponderables."222 What those "imperatives" and "imponderables" might be are open to debate.

Justice Jackson's concurrence did little to stem Curtiss-Wright's broad grant of power to the executive. Writing for the majority in Curtiss-Wright, Justice Sutherland held:

$[T]$ he very delicate, plenary and exclusive power of the President as the sole organ of the federal government im the field of international relations [is] a power which does not require as a basis for its exercise an act of Congress, but which, of course, like every other governmental power, must be exercised in subordination to the applicable provisions of the Constitution. ${ }^{223}$

Because the Constitution is thin on "applicable provisions" governing the President's conduct in foreign affairs, Sutherland, in essence, gave him free reign, while appearing to limit him. Meanwhile, the plenary and exclusive powers that Sutherland thought belonged to the Executive were rapidly expanding in the middle of the twentieth century and have reached a fevered pitch today. The Steel Seizure Cases did nothing to stem

218. Youngstown Sheet \& Tube Co. v. Sawyer, 343 U.S. 579 (1952).

219. United States v. Curtiss-Wright Export Corp., 299 U.S. 304 (1936).

220. Youngstown, 393 U.S. at 637.

221. Id.

222. Id.

223. 299 U.S. 304, 319-20 (1936). 
Sutherland's wide grant of power to the executive; they only provided a different framework for analyzing it.

The Curtis-Wright and Steel Seizure cases provided unsatisfactory answers because of their pliancy and because they lacked significant deliberation. Specifically, they asserted important policy positions not directly at issue in the case and premised their holdings on extra-precedential sources. Curiously, the Court is comfortable policing inconsistencies between the country's domestic laws and its international interests, as it did in Holland. There, it saw itself as best suited to elucidate the penumbra created by those inconsistencies. ${ }^{224}$ But when it comes to questions relating to horizontal separation of powers, the Court has been recalcitrant.

The Court's recent cases have continued the trend of deference to the executive in foreign affairs. In Dames \& Moore $v$. Regan, the Court suggested that the President could act first and get congressional authorization later under the Steel Seizure framework. ${ }^{225}$ Or, as Harold Koh has put it, "Dames and Moore radically undercuts the Youngstown vision of balanced institutional participation in the national security process . . by making it easier to find congressional approval and more difficult for Congress to express its institutional opposition." 226 In American Insurance Association v. Garamendi, the Court suggested that the President might be able to supersede state law by asserting the "foreign policy of the Executive Branch" as a rationale. ${ }^{227}$ Combined with its jurisprudence from the middle of the twentieth century, these cases make clear that the Court does not have the will to meaningfully check the executive in foreign affairs.

Ferreting out the meaning behind present-day institutional differences requires an understanding of the history of how things came to be the way they are.

\section{B. Reviving Bricker's Concerns}

The 1950s were a time of epochal change in the United States. The country emerged as a preeminent international power with massive

224. Thomas M. Franck, Delegating Aspects of Sovereignty to International Regimes, in Delegating State Powers: The Effect of Treaty Regimes on Democracy and Sovereignty 8 (Thomas M. Franck ed., 2000). Franck sees these determinations as resting somewhere between political questions and legal questions. He argues that black-letter law concerns should take a back seat to the "spirit or penumbra" of the Constitution. Id.

225. See 453 U.S. 654, 668-69 (1981) ("When the President acts in the absence of congressional authorization he may enter 'a zone of twilight in which he and Congress may have concurrent authority, or in which its distribution is uncertain.' In such a case the analysis becomes more complicated, and the validity of the President's action, at least so far as separation-of-powers principles are concerned, hinges on a consideration of all the circumstances which might shed light on the views of the Legislative Branch toward such action, including 'congressional inertia, indifference or quiescence."') (Internal citations omitted).

226. HaROLD HONGJU KoH, supra note 204, at 140.

227. 539 U.S. 396, 413 (2003). 
problems at home. Still hammering out questions of federalism, the country exhibited serious qualms about fully participating in and interacting with international organizations such as the U.N. But given the push of cold warriors with their red fear, it did not have much choice. The undue quickening that the government went through as a result left loose ends in the balances of power, loose ends that the executive branch eagerly grasped.

In his memoirs, President Eisenhower tried to debunk the argument that the Bricker Amendment controversy pitted "liberals" against "conservatives" or "isolationists" against "internationalists." $228 \mathrm{He}$ was right to an extent. Labels were not enough to explain the change that had come. Classifications such as liberal and conservative signify world views and values that framed the debate. Larger philosophical questions about the nature of the Constitution were at play, but before they could be answered, there had to be agreement on which branch of the federal government would provide the answers.

Strikingly, many of the executive practices questioned by the Brickerites are now commonplace. But in many ways the points they raised are germane to today's probleins. Instead of an executive who inay subjugate the United States to international organizations, we have one who many feel flaunts international standards. The debate has coine full circle, but the underlying answer is the saine: there should be more transparency in the executive's actions in the international field. In the 1950 s, communism provided the rationale for clandestine action. $\ln 2005$, the rationale is the war on terror. Both arguments place a premium on information, often at the cost of checks on executive authority. In the 1950s, information about communism and communist ideas was at a premium. Today, it is information that falls under the ever-growing umbrella of national security meant to shield the country from terrorist attack. The judiciary's ongoing failure to meaningfully curtail the executive's accumulation of power leaves the burden on Congress. Regardless of its institutional shortcomings, it should take the lessons of the Bricker Aunendment controversy and try again to check the executive. Many factors hindering Congress in the 1950s are no longer present.

Civil rights and segregation constantly lurked in the background of 1950s American foreign affairs. Many hoped the U.N. would force the United States to finally take off its cement shoes and make progress in bringing equal treatment to segregated blacks and other minorities. In 1947, the National Association for the Advancement of Colored People (NAACP) issued a pamphlet entitled, "An Appeal to the World," in which it appealed to the U.N. to redress wrongs perpetrated by America. ${ }^{229}$ The

228. DWight Eisenhower, Mandate For Change 284-85 (1963).

229. The National association for the Advancement of Colored People, An Appeal to the World: A Statement on the Denial of Human Rights to Minorities in the Case of 
appeal was part of a larger effort to apply U.N. standards to inequalities in the United States. Several court cases also dealt with the issue. Solicitor General Perlman, in oral arguments before the Supreme Court in Shelly v. Kraemer, argued that the United States' segregation practices made it difficult to conduct foreign relations. ${ }^{230}$ Plaintiffs in Hurd v. Hodge claimed that racially restrictive covenants violated "treaty obligations of the United States contained in the United Nations' charter."231 The Oyama ${ }^{232}$ and $\mathrm{Fujii}^{233}$ cases, favorite whipping boys of the Brickerites, also contained appeals to the United States' treaty obligations under the U.N. Charter.

Racism significantly tarnished American foreign policy in the 1940s and 1950s. Some feared that segregation would provide "grist to the European Mills of anti-Americanism." ${ }^{234}$ The response to this was profound. If America was going to wage an ideological war, it was going to have to change its domestic practices; Justice Douglas and Chief Justice Warren took this lesson to heart, and their doing so was partially responsible for the landmark school desegregation cases. ${ }^{235}$ The domestic changes effected by the Court served to bring American life and law a small step closer to the image of itself portrayed in its anti-Soviet rhetoric. The Court was not alone in making advances; Congress and the President contributed to the shift in American life. How and what they did are outside the scope of this Comment, but suffice it to say, there was more balance and unity of purpose between the branches than there was in the realm of foreign affairs.

Cast in the shadow of race relations in foreign affairs, Bricker's amendment, which would have given more discretion to states, was a bad idea. That does not mean, however, that it was, or is, a bad idea for Congress to assert more power in foreign affairs. The development of an active and expansive international political climate over-inflated the impor-

Citizens of Negro Descent in the United States of America and an Appeal to the United NATIONS FOR REDRESS (W.E.B. Du Bois ed., 1947).

230. Mary L. Dudziak, Cold War Civil Rights 91 (2000).

231. 334 U.S. 24,28 n.4 (1948).

232. 332 U.S. $633,649-50$ (1948) ("There are additional reasons now why that law stands as an obstacle to the free accomplishment of our policy in the international field. One of these reasons is that we have recently pledged ourselves to cooperate with the United Nations to 'promote ... universal respect for, and observance of, human rights and fundamental freedoms for all without distinction as to race, sex, language, or religion." (internal citations omitted)).

233. 38 Cal. 2d 718, 724 (1952) ("The humane and enlightened objectives of the United Nations Charter are, of course, entitled to respectful consideration by the courts and legislatures of every member nation, since that document expresses the universal desire of thinking men for peace and for equality of rights and opportunities. The charter represents a moral commitment of foremost importance, and we must not permit the spirit of our pledge to be compromised or disparaged in either our domestic or foreign affairs.").

234. Dudziak, supra note 230 , at 36 (citation omitted).

235. Id. at 105-06, 130-50 (discussing the importance that the school desegregation cases played in shaping America's image abroad). 
tance of the executive, in part, because Congress did not keep pace, ceding new areas of power as they came up. Oliver Wendell Holmes had it right when he wrote, in Holland, that constitutional questions "must be considered in the light of our whole experience." ${ }^{236}$ Bricker's quest and the rebalancing of power that took place after World War II provide a useful lens for reexamining how we arrived at the status quo of today that so many find unsatisfactory. More attention to Bricker and his travails would do the country well. 
